\title{
Meta
}

Journal des traducteurs

Translators' Journal

\section{The Translator as 'Language Planner': Syntactic Calquing in an English-Spanish Technical Translation of Chemical Engineering}

\section{Silvia Montero-Martinez, Pedro A. Fuertes-Olivera et Mercedes García de Quesada}

Volume 46, numéro 4, décembre 2001

URI : https://id.erudit.org/iderudit/003591ar

DOI : https://doi.org/10.7202/003591ar

Aller au sommaire du numéro

Éditeur(s)

Les Presses de l'Université de Montréal

ISSN

0026-0452 (imprimé)

1492-1421 (numérique)

Découvrir la revue

Citer cet article

Montero-Martinez, S., Fuertes-Olivera, P. A. \& García de Quesada, M. (2001).

The Translator as 'Language Planner': Syntactic Calquing in an English-Spanish

Technical Translation of Chemical Engineering. Meta, 46(4), 687-698.

https://doi.org/10.7202/003591ar
Résumé de l'article

Cet article porte sur la traduction technique ainsi que sur les conditions imposées aux experts exerçant des traductions et devant réconcilier les contraintes linguistiques d'une langue donnée avec les normes communicatives d'un certain champ spécialisé. Notre hypothèse est que les experts ont généralement recours au calque syntaxique afin d'exprimer des unités phraséologiques, dont les collocations lexicales. C'est ainsi que leur rôle de planificateurs linguistiques est renforcé, non seulement en introduisant de la terminologie dans la LA mais encore en imposant les normes de la LD à l'intérieur d'une communauté d'experts. C'est pour cette raison que le rôle de la traduction dans le processus de la documentation terminologique doit être mis en valeur. 


\title{
The Translator as 'Language Planner': Syntactic Calquing in an English-Spanish Technical Translation of Chemical Engineering
}

\author{
SILVIA MONTERO-MARTINEZ, \\ PEDRO A. FUERTES-OLIVERA AND \\ MERCEDES GARCíA DE QUESADA \\ University of Valladolid, Valladolid, Spain
}

\begin{abstract}
RÉSUMÉ
Cet article porte sur la traduction technique ainsi que sur les conditions imposées aux experts exerçant des traductions et devant réconcilier les contraintes linguistiques d'une langue donnée avec les normes communicatives d'un certain champ spécialisé. Notre hypothèse est que les experts ont généralement recours au calque syntaxique afin d'exprimer des unités phraséologiques, dont les collocations lexicales. C'est ainsi que leur rôle de planificateurs linguistiques est renforcé, non seulement en introduisant de la terminologie dans la LA mais encore en imposant les normes de la LD à l'intérieur d'une communauté d'experts. C'est pour cette raison que le rôle de la traduction dans le processus de la documentation terminologique doit être mis en valeur.
\end{abstract}

\section{ABSTRACT}

This article focuses on technical translation and the demands imposed on subject-field expert translators who must decide how they can reconcile the linguistic constraints imposed by a particular language with the communicative expectations found in a particular domain. Our main hypothesis is that experts typically resort to syntactic calquing to render phraseological units such as lexical collocations. By so doing they reinforce their role as language planners not only by introducing terminology into the TL but also by imposing SL norms within the expert community. Hence, the role of translation during the process of term documentation should be enhanced.

\section{MOTS-CLÉS/KEYWORDS}

technical translation, syntactic calquing, term documentation, linguistic constraints, communicative expectations

\section{Introduction}

The purpose of this article is twofold: (a) to show that technical translation is not very different from translating, say, literature (Seleskovitch 1988), and (b) to argue that translation contributes to term formation in the Target Language (TL) by exploiting resources such as syntactic calquing. El-Shiyab (1999: 206-207) claims that whatever definitions of translation we come across, almost all of them can be subsumed under two definitions. The first is "the replacement of one written text from one language to another in which the main goal of the translator is meaning. The second is the transference of a message communicated from one text into a message communicated in another, with a high degree of attaining equivalence of context of 
the message, components of the original text, and the semiotic elements of the text..." This second view seems to have more defendants these days, perhaps because of the enormous influence exerted by Discourse Analysis. Proponents of the first definition typically illustrate their claims with examples from technical translations where the transference of meaning seems paramount. In contrast, defendants of the second view claim that literary translation is a good example of their view since literary translation is mainly concerned with text functions. In this article, however, we offer an integrated approach by maintaining that technical translation should be not only concerned with transmitting meaning but also with the transference of communication in such aspects as, for example, following the terminological and phraseological conventions of the field in question. In other words, we agree with Sager (1992), who maintains that term formation is a conscious activity which uses pre-existing patterns and models, and with Galinski et al. (1993) who claim that to express the linguistic knowledge in technical texts, terminology (the group of terms characteristic of the subject matter) and LSP phraseology (the set of expressions and turns typical of the subject matter) are used. Consequently, linguistic knowledge and specific knowledge must go hand in hand. The Translated Text (TT), then, must be correct not only in its grammar but also in factors such as the loyalty of its contents with regard to the Source Text (ST), conceptual coherence, the degree to which it respects the receptor's stylistic conventions, and the communicative function. The notion of style here includes a range of elements, from the overall text structure to the selection of lexical elements at the sentence level, particularly terminology and phraseology (Cabré 1998; Wright, 1993).

\section{Technical Translation}

Our previous statement is in line with Seleskovitch's idea that "separate as they may be in the practice of individual translators, literary and technical translations have one aspect in common: they deal with texts, not only with languages" (Seleskovitch 1988: 83). This implies the use of co-text and extra-linguistic knowledge. Although different terms have been used (e.g. 'specialized translation,' 'scientific translation,' 'economic translation, etc.) we follow the current practice of using 'technical translation' to refer to the translation of LSP texts (Wright and Wright 1993). Technical translation is essentially a professional skill comprising, at the least, three basic requirements: (a) a clear comprehension of the source language, (b) knowledge of the subject, supported by access to reliable sources of the latest information, (c) and skills necessary to write on the discipline like an expert (Uvarov 1988; Wright \& Wright 1993; Cabré 1998).

Technical translation is currently performed either by professional translators or by experts in the subject matter. A debate on the pros and cons of both types of translators has been going on for a long time. Fuertes Olivera (1998) has claimed that this debate should also consider practical matters such as 'money' (i.e., how much is the fee for the translation), since on many occasions this is the main factor in the choosing of an expert or a professional translator. In this article we investigate the translational activity of an expert in Chemical Engineering. 


\section{The Data}

Our context of translation ${ }^{1}$ embraces the translation of a university manual on Chemical Engineering, entitled Equilibrium-Stage Separation Operations in Chemical Engineering by Henley, E. J. and J. D. Seader. The translator is Dr. Fidel Mato Vázquex, a university professor in Chemical Engineering at the Universidad de Valladolid, widely acknowledged for his mastery in the translation of this type of text. $^{2}$ In this vein, Dr. Fernández-Polanco, Head of the Chemical Engineering Department, and a number of students in this programme defended the validity of the text and commented that, in their opinion, the translation was excellent because it adapted the English phraseological and terminological patterns to Spanish standards. In other words, if it was classified as a valid translation by the experts and receptors of the text we could conclude that the technical translator should have combined an adequate knowledge of the languages involved in translation, including the discursive style of LPSs, with specific cognitive competence in the subject to be translated (Cabré 1998: 46). It must be argued, then, that this translation must present a real and adequate terminology and phraseology (Cabré 1998: 33). In accordance with the reading literature, technical translations carried out by experts in the field offer fluency and conceptual coherence in the written discourse of the TL for three basic reasons: (i) knowledge of the specific subject, (ii) the understanding of its terminology and phraseology (given a sufficient linguistic competence in the working languages), and (iii) the ability to adjust to the communicative situation which is reflected in the context-conditioned variants of terminology and phraseology (Nkwenti-Azeh 1998: 160). Hence, the translator should have maintained the same didactic function of the ST in the TT.

This study was limited to 63 lexical collocations (Appendix 1). To investigate the influence of translators on language planning, we divided our corpus into two related sets: the English text and its translation. We, then, used the WordSmith concordancer to run a concordance search on five terms selected by experts at the Chemical Engineering Department, who considered them 'relevant' in this subject field: 'liquid,' 'vapor,' 'phase,' 'pressure' and 'equilibrium.'3 Example:

[1] English version: directing of the vapor flow to propel the liquid across the tray

[2] Spanish translation: dirigir el flujo de vapor de forma que fuerce el líquido a circular a través del plato

\section{Results and Discussion}

LSP phraseology studies the phraseological units in specialized discourse. In LSP English, these units comprise a very limited group that can be divided into four categories: nominations (e.g. malignant tumor), irreversible binomials (e.g. supply and demand), collocations (e. g. to induce an abortion), and routine formulae (e.g. approaching vessels please acknowledge). Collocations are defined as habitual combinations of words, more or less fixed, whose meaning can be worked out from each component (Cowie 1994; Glässer 1994/95; Roberts 1994/5). Benson et al. (1993) classify them into grammatical and lexical collocations. The former consist of a dominant word (noun, adjective or verb) and a preposition, an infinitive or a clause. The latter consist of two 'equal' elements. According to its structure, they are currently separated into seven groups: 
L1: verb (usually transitive) + noun/pronoun (or prepositional phrase): e.g. compose music; launch a missile.

L2: verb + noun: e.g. demolish a house; annul a marriage.

L3: adjective + noun or noun (attributive) + noun: e.g. strong tea; a chronic alcoholic.

L4: noun + verb indicating an action proper of the person or thing designated by the noun: e.g. blood circulates; bees buzz.

L5: noun $1+$ of + noun2, indicating the measuring unit associated with noun2: e.g. $a$ pack of dogs; an act of violence.

L6: adverb + adjective: e.g. strictly accurate

L7: verb + adverb: e.g. appreciate sincerely

In general terms, it is accepted that translating these units is difficult because they emerge out of the use that a given community is engaged in (Glässer 1994/95: 53), contribute to maintain the lexical cohesion of a text-also a very important element for translators (Rabadán 1996) —and imply the understanding of conceptual relations in the knowledge domain and its occurrences in the discourse depending on the communicative setting (Sager 1992: 109). In certain disciplines-for example, in Economics-these difficulties increase since the transfer of knowledge demanded at present by the general public makes it difficult, say, to draw a line between terms and common words (Holljen 1999).

Special languages are not only characterized by terms but also by phraseology, which may be as specific as terminology (Cabré 1998: 51). The existence of a relationship between terminology and phraseology is subject to debate. We follow Roberts (1994/95) and Pitch (1991) by accepting that LSP phraseology is a fundamental subdiscipline of terminology, which would explain our belief that translation of these units must be carried out considering both their linguistic implications and conceptual combinations. In other words, technical and literary translators face a similar dilemma: how can they reconcile the linguistic constraints imposed by a particular language with the expectations found in a particular domain? We should not forget that most terms gain currency and widespread use in the language in which they were produced. Many experts are familiar with them and, where possible, have adapted them to their native languages, at least in their informal conversations with colleagues. For example, the English term 'batch process' is currently referred to by chemical engineers as 'proceso por baches,' a Spanish adaptation. ${ }^{4}$ In other cases, experts continue using the foreign term, perhaps because of structural constraints which make the adaptation difficult. For example, Spanish chemical engineers use many English terms in their discussions. Some of these are 'stripping,' 'piping,' etc. These processes illustrate the use of a particular language as lingua franca, which in some cases seem to be in contradiction with nationalist language policies aimed at coining their own terms in every possible context. In the sci-tech environment, for example, less developed societies become receptors of different kinds of borrowings: cultural, scientific, technical and linguistic (Holljen, 1999; Alcaráz et al. 1998; Estevez, 1997; Kyjak et al. 1996; Godman et al. 1990; Neubert 1990). These societies, then, should rest on translators who, on many occasions, create neologisms or resort to different strategies to overcome the difficulties which would prevent them from transferring innovative contents from the ST to the TT (Goffin 1990). In our case, the expert translator guarantees fluency in the written discourse of the TT by making use of a rather polemical formula for translating the lexical collocations here considered: syntactic calquing. 
Calquing is a method of linguistic borrowing. Sampson (1995) and Kyjak et al. (1996), for example, argue that calquing is very productive. Although there has been terminological and conceptual confusion around this term (Santoyo 1987), we argue that in the context of English-Spanish translation, calquing can be defined as linguistic elements, or groups of these which are used in Castillian Spanish through English influence, although the linguistic elements comprising this unit are recognized as Spanish (Pratt 1980). Calques can be divided into loan meanings and loan formations. Loan meanings consist in the semantic expansion of a given Spanish word to include a typical English meaning. These semantic borrowings are mainly due to cognation and paronym (Lorenzo 1996; Mwansoko 1991; Neubert 1990; MeunierCrespo 1987). For example, the Spanish adjective 'dramático' has taken the additional meaning of 'espectacular' ('exciting' or 'impressive') because of the influence of the English adjective 'dramatic.' Loan formations or loan creations are foreign words with an outwardly Spanish appearance. In our case, they were adopted from English with little or no modification. Although most of them are not registered in dictionaries, Spanish speakers recognize them as part of the Spanish lexicon. They may be one-word formations (e.g. 'privacidad' from 'privacy') or complex formations (Mwansoko 1991). The latter formations are called syntactic calques in this article. Basically they are loan translations adopted by one language from another either literally (e.g. 'terapia ocupacional' from 'occupational therapy') or less literally (e.g. 'telón de acero' from 'iron curtain') depending on the structural constraints imposed by the TL. In some cases, these complex formations create new complex terms in the SL because they usually designate conceptual innovations (Alcaraz et al 1998; Kyjak et al. 1996; Lorenzo 1996; Meunier-Crespo 1987; Santoyo 1987).

In the reading literature it is often assumed that calques are abundant in the Romance languages, particularly in technical fields (Santoyo 1987), perhaps because translators are more favorable to calquing than to pure anglicisms when borrowing since on many occasions they go unnoticed (Alcaraz et al. 1998; Calvi 1998; Molina 1997). This use of calquing is easily documented in the language of computers (e.g. 'formatear un disco' from 'format a disk'), in the language of medicine and pharmacology (e.g. 'tratar una enfermedad con' from 'treat a disease with'), and in the language of economics (e.g. 'crédito documentario' from 'documentary credit') (Alcaraz et al 1998; Navarro 1995; Navarro et al 1994, 1992;; Ordoñez 1990; Meunier-Crespo 1987). To determine whether similar or different strategies were being used in the subject field of Chemical Engineering, we have embarked on a research project dealing with this specialized language variety. In this initial article, we have investigated the translation strategy used by the translator in question to render the 63 lexical collocations of the types L1, L2 and L4 identified under the nodes referred to above:

TABLE 1

Translation Strategies used for rendering English lexical collocations into Spanish.

\begin{tabular}{|lcc|}
\hline Translation Strategy & Number & $\%$ \\
\hline (i) Phraseological Unit & 56 & 88.9 \\
(ii) Paraphrase & 4 & 6.3 \\
(iii) Single lexeme & 1 & 1.6 \\
(iv) Missing & 2 & 3.2 \\
\hline Total & 63 & 100 \\
\hline
\end{tabular}

Source: Montero (1999) 
In short, the translator relies on 4 possible strategies: (i) phraseological unit (PU), (ii) paraphrase (P), (iii) single lexeme (L), (iv) missing (M). Examples:

[3a] PU: 'enriquecer vapor' from 'to enrich vapor' 'operar a presión' from 'to operate under pressure' 'alcanzar el equilibrio' from 'to attain equilibrium'

[3b] P: 'forzar líquido a circular' from 'to propel liquid' 'descender líquido en forma de lluvia' from 'to spray liquid'

[3c] L: 'desplazar el azeótropo' from 'to shift the equilibrium'

[3d] M: $\quad \varnothing$ from 'for making contacts with liquid'

Although we are aware that our corpus is very limited, our data are rather promising because they are in line with similar research reported in the reading literature: technical translators resort to syntactic calquing for rendering complex terms. If the existence of this strategy were to be totally confirmed we might teach our translation students its importance in the translation of specialized texts. In addition, it might shed new light on the old debate about the role calquing plays in translation. On the one hand, language nationalists defending peculiarities and cultural identities claim that calquing only reflects the translator's ignorance of the TL (Garcia Yebra 1995). Their arguments against this strategy may be summarised in the idea that different languages show structural and semantic divergences. Hence, calquing would be an artificial morpho-syntactic manipulation of the TL and evidence that different cultures risk losing their own identities due to the current process of globalization. Translation, therefore, would be just another feature of this process (Arntz 1988; Boulanger 1987; Klein-Lataud et al. 1986). On the other hand, globalists argue that calquing is positive because it favours innovation and development. They claim that technical translation involves innovation not only in content but also in form. It acts as a fertilizer to the communicative techniques of the TL, especially on terminology where translation seems better than artificial creation (Calvi 1998; Rajaspera 1996; Narayana 1994; Godman et al. 1990; Neubert 1990; Meunier-Crespo 1987; Santoyo 1987). This second view seems to hold more promise, and is in line with recent trends in translation research defending the use of corpus linguistics (Laviosa 1998). The analysis of real data might confirm not only the role of calquing as a terminology fertilizer, but also its contribution to the internationalization of terminologies (Santoyo 1987). Taking into consideration the conditioning elements of most translation processes-for example, time constraints, background knowledge, previous contact with new terms in the source language, etc.- - we might conclude that the use of calquing is not only inevitable in technical translation but is also a form of language planning, although this dimension has never been officially acknowledged (Holljen 1999). In other words, we agree with Narayana (1994) that most of what we take as convergence has its origin in the translatorial actions taken by members of the speech community who use them as gap-filling devices in the terminological and phraseological context of the TL.

\section{Conclusion}

In this article we have shown that technical translation contributes to term formation and that technical translators should confront demands similar to those of literary 
translators: they should be concerned not only with transmitting meaning but also with the transference of communication. In other words, technical and literary translators must decide how they can reconcile the linguistic constraints imposed by a particular language with the communicative expectations found in a particular domain. To illustrate these claims we have analyzed how a subject-field expert has rendered English lexical collocations of the types L1, L2 and L4 into Spanish. Our results confirm that these types of translators resort to syntactic calquing to render phraseological units, thus reinforcing their role as language planners not only by introducing terminology into the TL, but also by imposing SL norms within the expert community. Hence, two related questions need to be addressed: (i) can professional translators also act as language planners, in this case by suggesting more appropriate terms, linguistically speaking? (ii) is it possible to embark on a terminology project claiming that translations should not be considered reliable sources during the process of documentation? Corpus linguistics might provide the resources necessary to answer both questions. At this stage we suggest that calquing is inevitable because it reflects the present trend in favour of internationalization, promotes national languages, and contributes to homogenization among languages. And by so doing it favours semantic unity. In other words, calques maintain a link between a TL and international terminologies. In this situation, then, the subject-field expert translator-and his or her tendency towards calquing - acts as a language international planner.

\section{ACKNOWLEDGMENTS}

Thanks are due to Marisol Velasco Sacristán and Ascensión Arribas Baño for their comments on an earlier draft of this article.

\section{NOTES}

1. Godman et al. (1990) claim that it is through the description of this context that we can give account for the decisions taken in the translation process, decisions such as the translation or non translation of a given text.

2. For example, in the Industrial Engineering Chemistry Research a reviewer comments that the "Spanish translation-by Mato Vázquez from Salamanca, coincidentally also the translator of the McCabe and Smith's Unit Operations in Chemical Engineering $(1956,1972)$-was impeccable, down to preserving the secret dedication to Haugen in the preface and readapting the "on Wisconsin" message in the postface." This comment refers to Transport Phenomena, perhaps one of the most influential manuals in the last 35 years. Presently, it is in its 50th printing and has sold approximately 200,000 authorized copies. INDUSTRIAL ENGINEERING CHEMISTRY RESEARCH, 34-10, pp. 3183.

3. They yielded 973 concordances, 63 of which were, as we said before, classified as lexical collocations.

4. The Spanish word 'bache' means 'pothole,' 'air pocket,' 'bad time' or 'gap' (Diccionario Oxford español-inglés/ inglés-español).

5. 'Missing' corresponds to English lexical collocations which were not found in the Spanish version

\section{REFERENCES}

Alcaráz Ariza, M. A. and N. Congost Maestre (1998): "Los anglicismos y su (no) traducción al español en textos médicos," L. Félix Fdez. and E. Ortega Arjonilla (Coords.), II Estudios sobre traducción e interpretación. Tomo III, Málaga, CEDMA, pp. 1035-1041.

ArNtz, R. (1988): "Le Rôle des internationalismes dans la formation des traducteurs," META, 334, pp. 497-505. 
Benson, M., Benson, E. and R. Ilson (1993) [1986]: The BBI combinatory dictionary of English: A guide to word combinations, Amsterdam/Philadelphia, John Benjamins Publishing Company.

BoulAnger, J.C. (1987): “Le miroir aux alouettes en intelligence artificielle," META, 32-3, pp. 326-331.

Cabré Castellví, Ma.T. (1998): “Las fuentes terminológicas para la traducción,” P. Fernández Nistal and J.Ma. Bravo Gozalo (Coords.), La traducción: Orientaciones lingüísticas y culturales, Valladolid, Universidad de Valladolid (SAE), pp. 27-59.

Calvi, M.V. (1998): “Notas sobre la adopción de anglicismos en español y en italiano," LEA, 201, pp. 29-39.

Cowie, A.P. (1994): "Phraseology," R.E. Asher (Ed.), The encyclopedia of language and linguistics, Vol. 6, Oxford and New York, Pergamon, pp. 3168-3171.

EL-Shiyab, S. (1999): “The difficulty of translating literary texts," BABEL, 45-3, pp. 205-216

Estévez Eguiagaray, C. (1997): "La colaboración con profesionales de los campos específicos en la traducción especializada," M. A. Vega and R. Martín Gaitero (Eds.), La palabra vertida: Investigaciones en torno a la traducción, Actas de los VI Encuentros Complutenses en torno a la traducción, Madrid, Ed. Complutense, pp. 407-413.

Fuertes Olivera, P. A. (1998): "Metaphor and translation: a case study in the field of Economics," P. Fernández Nistal and J. M. Bravo Gozalo (Eds.), La Traducción: Orientaciones Lingüísticas y Culturales, Valladolid, Universidad de Valladolid (SAE), pp. 79-95.

Galinski, C. and G. Budin (1993): "New trends in translation-oriented terminology management," S.E. Wright and L. Wright (Eds.), Scientific and technical translation, Amsterdam/ Philadelphia, John Benjamins, pp. 209-215.

García Yebra, V. (1995): "Responsabilidad del traductor ante su propia lengua," M.A. Vega and R. Martín Gaitero (Eds.), V Encuentros Complutenses en torno a la Traducción, Madrid, Ed. Complutense, pp. 629-640.

GLÄSER, R. (1994/95): "Relations between phraseology and terminology with special reference to English," ALFA, 7-8, pp. 41-60.

Godman, A. and R. Veltman (1990): "Language development and the translation of scientific texts," BABEL, 36-4, pp. 193-212.

Goffin, R. (1990): "L'Europe en neuf langues: Champ d'affrontements et ferment d'integration linguistiques," META, 35-1, pp. 13-19.

Henley, E.J. and J.D. SeAder (1981): Equilibrium-stage separations operations in chemical engineering, New York, John Wiley \& Sons.

Henley, E.J. and J.D. SEAder (1988): Operaciones de separación por etapas de equilibrio en Ingeniería Química, Barcelona, Reverte. Translated by F. Mato Vázquez.

Holljen, M. (1999): "Translation studies at a crossroads: Educating translators in minor language communities-a key element in the language planning of modern Norwegian," TRANSLATION JOURNAL, 3-1, <http://accurapid.com/journal/07educ.htm>.

Klein-Lataud, C. and C. Tatilon (1986): "La traduction des structures grammaticales," META, 31-4, pp. 370-376.

Kyjak, T., Ivanitskiy, R. and O. LhotKa (1996): "Distinguishing between international words and lexical borrowings," TERMNET NEWS, 52-53, pp. 23-26.

Laviosa, S. (1998): "The corpus-based approach: A new paradigm in Translation Studies," META, 43-4, pp. 474-479.

Lorenzo, E. (1996): Anglicismos hispánicos, Madrid, Gredos.

Meunier-Crespo, M. (1987): "Les anglicismes dans la presse d'information économique espagnole," META, 32-3, pp. 273-277.

Molina Plaza, S. (1997): "Anglicismos léxicos y sintácticos en la traducción literaria de textos del inglés al español," M. A. Vega and R. Martín Gaitero (Eds.), La palabra vertida: Investigaciones en torno a la traducción, Actas de los VI Encuentros Complutenses en torno a la traducción, Madrid, Ed. Complutense: 621-628. 
Montero Martínez, S. (1999): La traducción de la fraseología especializada: Análisis de colocaciones léxicas en el campo de la ingeniería química, Unpublished MA Dissertation, Departamento de Lengua y Literatura Inglesa y Alemana, Universidad de Valladolid.

Mwansoko, H.J.M. (1991): "Swahili terminological modernization in Tanzania. What are the register user's views?,” META, 36-1, pp. 301-310.

Narayana Singh, U. (1994): “Translation as a way of growing," META, 39-2, pp. 401-403.

Navarro, F.A. (1995): “Tercer listado de palabras de traducción engañosa en el inglés médico," MEDICINA CLÍNICA, 105-13, pp. 504-514.

Navarro, F.A. and F. Hernández (1994): "Nuevo listado de palabras de traducción engañosa en el inglés médico," MEDICINA CLÍNICA, 102-4, pp. 142-149.

Navarro, F.A. and F. Hernández (1992): "Palabras de traducción engañosa en el inglés médico," MEDICINA CLÍNICA, 99-15, pp. 575-580.

Neubert, A. (1990): "The impact of translation on target language discourse text vs. system," META, 35-1, pp. 96-101.

Nkwenti-Azen, B. (1998): "Information mediation: The interface between terminology and translation," A. Kent (Ed.), Encyclopedia of Library and Information Science, Vol. 62, (Supplement 25), New York/Basel/Hong Kong, Marcel Dekker, pp. 157-170.

Ordoñez Gallego, A. (1990): “Algunos barbarismos del lenguaje médico," MEDICINA CLÍNICA, 94-10, pp. 381-383.

Pratt, C. (1980): El anglicismo en el español peninsular contemporáneo, Madrid, Gredos.

PIснт, H. (1991): “Fraseología LSP desde el punto de vista terminológico," SENDEBAR, 2, pp. 91105.

Rabadán, R. (1996): "El papel de la lingüística en los estudios de traducción: Usos y aplicaciones," P. Fernández Nistal and J.Ma. Bravo Gozalo (Coords.), A spectrum of translation studies, Valladolid, Universidad de Valladolid (SAE), pp. 91-103.

Rajaspera, R. (1996): "Pour la création d'une terminologie scientifique et technique en Malgache," META, 41-3, pp. 435-458.

Roberts, R. P. (1994/95): "Identifying the phraseology of LSPs," ALFA, 7-8, pp. 61-73.

SAGER, J.C. (1992): "The translator as terminologist," C. Dollerup, A. Lsingor and D. Loddegaard (Eds.), Teaching translation and interpreting: Training, talent and experience, Amsterdam, John Benjamins Publishing Company, pp. 107-122.

Sampson, K. A. (1995): "Le rôle linguistique du français et de l'anglais dans l'expression des concepts techniques et semi-techniques dans les langues africaines," META, 40-1, pp. 73-80.

SAntoyo, J.C. (1987): "Traduction, fertilisation et internationalisation: Les calques en espagnol," META, 32-3, pp. 240-249.

Seleskovitch, D. (1988): “Technical and Literary Translation: A unifying view," C. Picken (Ed.), Translators and Interpreters Mean Business, Proceedings of the Second Annual Conference of the Institute of Translation and Interpreting, London, Aslib, pp. 83-88.

Uvarov, E. B. (1988): "Scientific Translation— pitfalls and problems," C. Picken (Ed.), Translators and Interpreters Mean Business, Proceedings of the Second Annual Conference of the Institute of Translation and Interpreting. London, Aslib, pp. 90-98.

Wright, S.E. (1993): "The inappropriateness of the merely correct: Stylistic considerations in scientific and technical translation," S.E. Wright and L. Wright (Eds.), Scientific and technical translation, Amsterdam/Philadelphia, John Benjamins, pp. 69-86.

Wright, S.E. and L. Wright (1993): "Editors' preface: Technical translation and the American translator," S.E. Wright and L. Wright (Eds.), Scientific and technical translation, Amsterdam/ Philadelphia, John Benjamins, pp. 1-7. 


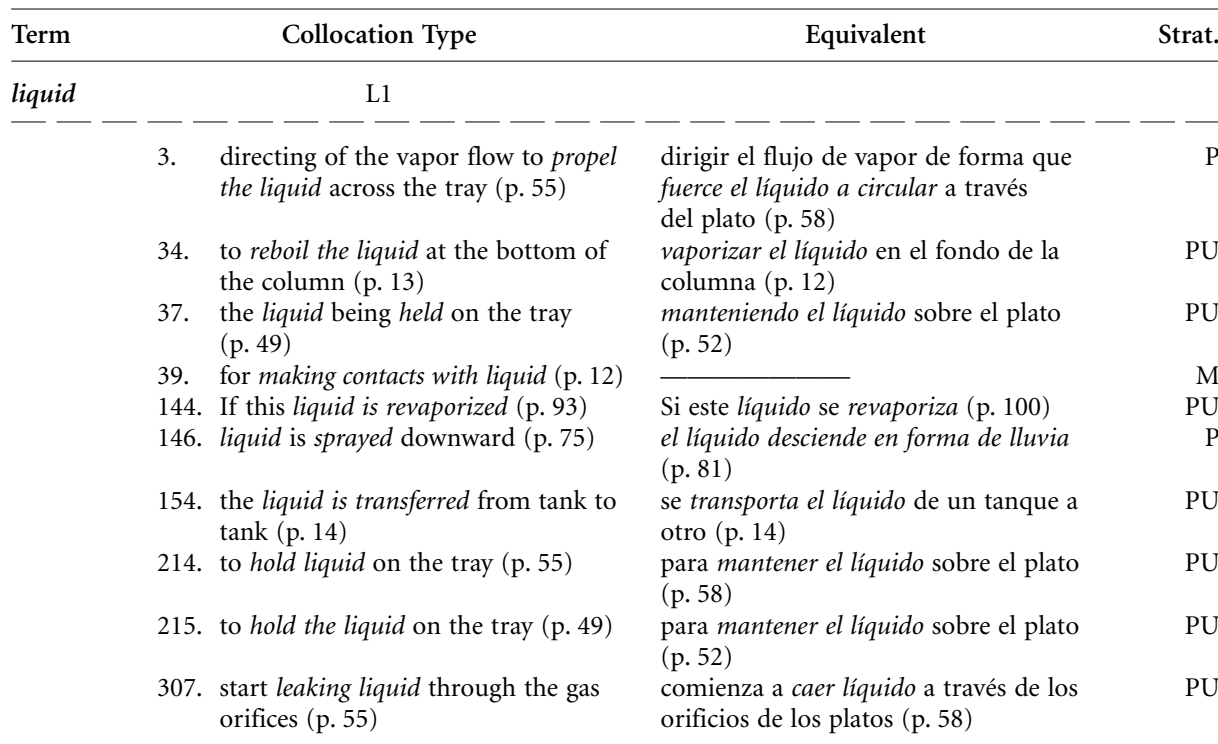

16. where the liquid and vapor flow through the same openings (p. 68)

33. liquid at the bottom of the column passes through a reboiler (p. 12)

59. one sees that the liquid descends through the downcomer (p. 68)

67. Liquid enters the base of the cap through the slot (p. 71)

125. a cylindrical vessel (...) through which the gas or liquid flows (p. 16)

222. Feed vapor passes up the column; feed liquid passes down (p. 12)

271. with the liquid rapidly spinning about each coil (p. 62)

308. there may be insufficient liquid to wet the surface (p. 53)

324. Will the liquid wet the packing? (p. 63)

328. through the liquid, which flows in and around the packing (p. 49)

330. Correspondingly, liquid, while flowing to the botton (p. 12) en los que el líquido y el vapor fluyen a PU

través de los mismos orificios (p. 72)

el líquido procedente del fondo de la PU

columna pasa a un calderín (p. 12)

se observa que el líquido baja por el tubo PU

de descenso (p. 72)

El líquido entra por la base de la caperuza PU

a través de una ranura (p. 75)

un tanque cilíndrico (...) a través del

cual fluye el gas o el líquido (p. 14)

El vapor de la alimentación pasa hacia $\quad P$

arriba en la columna mientras que

el líquido lo hace hacia abajo (p. 11, 12)

en ellas el líquido se extiende rápidamente $\quad \mathrm{P}$

formando hilos sobre cada hélice (p. 65)

puede no haber suficiente líquido para

mojar la superficie (p. 56)

¿Mojará el líquido al relleno? (p. 67)

PU

a través del líquido, que fluye por el

interior y alrededor del relleno (p. 53)

L1

87. If the vapor is then condensed (p. 138)

202. adding vapor to or from a gas (p. 13)

209. Vapor, (...), is increasingly enriched (p. 12)

210. the vapor will be superheated (p. 179)
Si después se condensa el vapor (p. 149) PU

se adiciona vapor hacia o desde un gas

PU

(p. 13)

el vapor $(. .$.$) se enriquece progresiva- \quad \mathrm{PU}$ mente (p. 11)

el vapor estará sobrecalentado (p. 194) 


\begin{tabular}{|c|c|c|c|}
\hline Term & Collocation Type & Equivalent & Strat. \\
\hline \multicolumn{4}{|c|}{$\mathrm{L} 2$} \\
\hline & $\begin{array}{l}\text { 202. removing vapor to or from a gas } \\
\text { (p. 13) }\end{array}$ & $\begin{array}{l}\text { se retira vapor hacia o desde un gas } \\
\text { (p. 13) }\end{array}$ & PU \\
\hline \multicolumn{4}{|c|}{$-----\overline{\mathrm{L} 4}$} \\
\hline & $\begin{array}{l}\text { 63. the vapor flowing up the middle } \\
\text { (p. 53) }\end{array}$ & $\begin{array}{l}\text { mientras que el vapor circula por la parte } \\
\text { central (p. } 56 \text { ) }\end{array}$ & PU \\
\hline & 91. the vapor leaving the cap (p. 69) & saliendo el vapor de la caperuza (p. 75 ) & $\mathrm{PU}$ \\
\hline & $\begin{array}{l}\text { 128. Feed vapor passes up the column } \\
\text { (p. 12) }\end{array}$ & $\begin{array}{l}\text { El vapor de la alimentación pasa hacia } \\
\text { arriba en la columna (p. 11) }\end{array}$ & PU \\
\hline & 194. vapor rising through orifices (p. 68) & $\begin{array}{l}\text { el vapor que asciende a través de los } \\
\text { orificios (p. } 72 \text { ) }\end{array}$ & PU \\
\hline \multicolumn{4}{|l|}{ phase } \\
\hline & 18. without creating a new phase (p. 90) & sin crear una nueva fase (p. 97) & PU \\
\hline & $\begin{array}{l}\text { 21. This second phase can be created by } \\
\text { (p. 7) }\end{array}$ & $\begin{array}{l}\text { Esta segunda fase se puede generar por } \\
\text { medio de (p. } 7 \text { ) }\end{array}$ & $\mathrm{PU}$ \\
\hline & 88. the vapor phase is enriched (p. 7) & la fase de vapor se enriquece (p. 11) & PU \\
\hline & $\begin{array}{l}\text { 93. while the liquid phase is enriched } \\
\text { (p. } 7 \text { ) }\end{array}$ & $\begin{array}{l}\text { mientras que la fase líquida se enriquece } \\
\text { (p. 11) }\end{array}$ & PU \\
\hline & $\begin{array}{l}\text { 104. a second phase may be created by } \\
\text { (p. } 7 \text { ) }\end{array}$ & $\begin{array}{l}\text { se puede generar una segunda fase por } \\
\text { (p. } 7 \text { ) }\end{array}$ & PU \\
\hline & $\begin{array}{l}\text { 155. the two phases become one phase } \\
\text { (p. 107) }\end{array}$ & $\begin{array}{l}\text { ambas fases se transforman en una sola } \\
\text { (p. 115) }\end{array}$ & PU \\
\hline \multicolumn{4}{|c|}{$-----\overline{\mathrm{L} 2}$} \\
\hline & $----\frac{\mathrm{L} 4}{-}---$ & $---\ldots-\cdots$ & - \\
\hline & $\begin{array}{l}\text { 147. a (...) phase that continuously } \\
\text { contacts the other (p. } 37)\end{array}$ & $\begin{array}{l}\text { una fase (...) que de forma continua } \\
\text { contacta con la otra (p. } 39)\end{array}$ & PU \\
\hline \multicolumn{4}{|l|}{ pressure } \\
\hline & $\begin{array}{l}\text { 4. throttled by valves to regulate stage } \\
\text { pressure (p. 26) }\end{array}$ & $\begin{array}{l}\text { controladas por válvulas con el fin de } \\
\text { regular la presión de la etapa (p. } 26)\end{array}$ & $\overline{\mathrm{PU}}$ \\
\hline & $\begin{array}{l}\text { 23. pressure can be calculated as a } \\
\text { function ( } \mathrm{p} .149)\end{array}$ & $\begin{array}{l}\text { se puede calcular la presión como una } \\
\text { función (p. 161) }\end{array}$ & PU \\
\hline & 78. the pressure is fixed (p. 91) & la presión está fijada (p. 98) & $\mathrm{PU}$ \\
\hline & 79. If the pressure is specified (p. 90) & Si la presión está especificada (p. 43) & PU \\
\hline & $\begin{array}{l}\text { 84. vapor pressure may be estimated } \\
\text { from (p. 158) }\end{array}$ & $\begin{array}{l}\text { la presión de vapor se puede estimar a } \\
\text { partir (p. 172) }\end{array}$ & PU \\
\hline & 85. to change pressure (p. 3 ) & para modificar la presión (p. 3) & PU \\
\hline & $\begin{array}{l}\text { 92. calculate the vapor pressure of } \\
\text { (p. 181) }\end{array}$ & calcúlese la presión de vapor del (p. 197) & PU \\
\hline & 102. operating under pressure (p. 51) & que opera a presión (p. 54) & PU \\
\hline & $\begin{array}{l}\text { 106. the saturation pressure (...) can be } \\
\text { estimated from (p. 158) }\end{array}$ & $\begin{array}{l}\text { la presión de saturación (...) se puede } \\
\text { estimar a partir de (p. 171) }\end{array}$ & PU \\
\hline & 122. by changing the pressure (p. 101) & modificando la presión (p. 109) & $\mathrm{PU}$ \\
\hline & 127. If we raise the pressure to $\mathrm{E}$ (p. 90) & Si se aumenta la presión hasta E (p. 97) & PU \\
\hline & $\begin{array}{l}\text { 133. Both (...) and total pressure will be } \\
\text { maintained constant (p. 138) }\end{array}$ & $\begin{array}{l}\text { Tanto (...) como la presión total } \\
\text { permanecerán constantes (p. } 148)\end{array}$ & PU \\
\hline
\end{tabular}




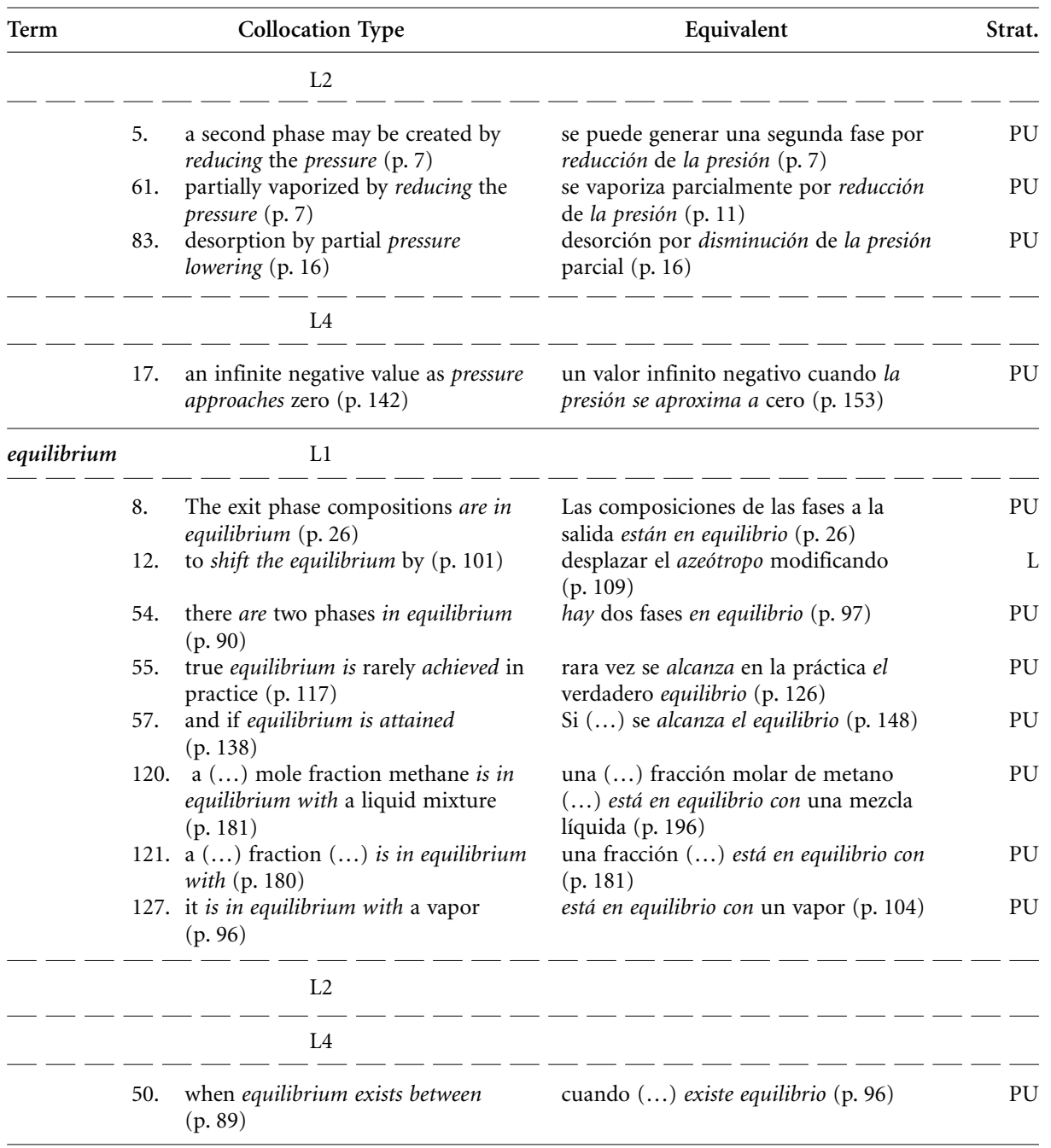

